\title{
BIOSYNTHESIS OF SILVER NANOPARTICLES USING PUTRI MALU (MIMOSA PUDICA) LEAVES EXTRACT AND MICROWAVE IRRADIATION METHOD
}

\section{BIOSINTESIS NANOPARTIKEL PERAK MENGGUNAKAN EKSTRAK DAUN PUTRI MALU (MIMOSA PUDICA) DAN IRADIASI GELOMBANG MIKRO}

\author{
Is Fatimah ${ }^{1}$, Nur Afisa Lintang Mutiara ${ }^{1}$ \\ ${ }^{1}$ Chemistry Department, Universitas Islam Indonesia, Yogyakarta, Indonesia \\ *email: isfatimah@uii.ac.id
}

Received 10 July 2016; Accepted 28 September 2016; Available online 29 November 2016

\begin{abstract}
In this paper, the biosynthesis of silver nanoparticles (AgNPs) using Mimosa pudica extract is discussed. Mimosa pudica leaves extract using water as a solvent was used as bio-reductor to an aqueous solution of silver nitrate $\left(\mathrm{AgNO}_{3}\right)$ and to accelerate the reduction, microwave irradiation method was applied. The AgNPs obtained were characterized using UV-Vis spectrophotometry, Fourier-Transform Infra-Red (FTIR) spectrophotometry, x-ray diffraction (XRD), scanning electron microscopy-energy dispersive X-ray (SEMEDX), tunneling electron microscopy (TEM) and particle size analysis based on dynamic scattering method. Effect of preparation method on the formation of AgNPs is also evaluated in antibacterial activity towards E.coli and P. aeruginosa. Rapid and ecofriendly biosynthesis of stable silver nanoparticles was observed in this study. The characterization results and antibacterial assay indicated the uniform and smaller particle size of AgNPs obtained by using microwave method the more homogeneous and smaller particle size distribution was obtained with similar antibacterial activity against tested bacteria obtained by aging method.
\end{abstract}

Keywords: Antibacterial activity; Microwave; Mimosa pudica; Silver nanoparticles

\section{ABSTRAK}

Dalam makalah ini disajikan kajian biosintesis nanopartikel perak( AgNPs) menggunakan ekstrak daun Putri Mau (Mimosa pudica). Ekstrak daun Mimosa pudica diperoleh menggunakan air sebagai pelarut dalam ekstraksi dan kemudian digunakan sebagai bioreduktor terhadap larutan perak nitrat $\left(\mathrm{AgNO}_{3}\right)$ serta dalam rangka memperepat reuksi digunakan metode iradiasi gelombang mikro. AgNPs yang diperoleh dikarakterisasi menggunakan spektrofotometri UV-tampak, spektrofotometri FTIR, SEM-EDX, dan analisis partikel berbasis metode pendaran dinamik. Pengaruh metode preparasi terhadap pembentukan AgNPs dievaluasi pada uji aktivitas antibakterinya terhadap E.coli dan P. aeruginosa. Metode biosintesis cepat dan ramah lingkungan dari AgNPs diperoleh dari penelitian ini. Hasil penelitian menunjukkan bahwa metode iradiasi gelombang mikro menghasilkan ukuran partikel yang lebih kecil dan seragam dengan aktivitas antibakteri yang sebanding dengan metode pemeraman.

Kata-kata kunci: Aktivitas antibakteri; Microwave; Mimosa pudica; Silver nanoparticles

\section{INTRODUCTION}

At present time nanoscience including nanochemistry becomes the main growing topics for many applications. The basic idea of the technology is nanometer-size particles that contribute to having unique properties and considerably excellent physical, chemical and biological properties compared to their macro scaled sized or called as quantum size effect. Silver nanoparticles
(AgNPs) is one of these developing nanoparticles for such applications ranging from catalysis and photocatalysis, water treatment, cancer detection, therapeutic and antibacterial agent. Such developments were attempted within the scheme of nanotechnology for instance designing AgNPs size with the higher the antibacterial activity (Dos Santos et al., 2014; Firdhouse \& Lalitha, 2015). 
Table 1. Researchers on the utilization of plant extract for AgNPs synthesis

\begin{tabular}{|c|c|}
\hline Researcher, year & Plant extract \\
\hline $\begin{array}{l}\text { (Rout, Behera, Ojha, } \\
\text { \& Nayak, 2012) }\end{array}$ & $\begin{array}{l}\text { Ocimum } \\
\text { (Tulashi) }\end{array}$ \\
\hline $\begin{array}{l}\text { (Banerjee, Satapathy, } \\
\text { Mukhopahayay, \& } \\
\text { Das, 2014) }\end{array}$ & $\begin{array}{l}\text { Musa balbisiana } \\
\text { (banana), Azadirachta } \\
\text { indica (neem) and } \\
\text { Ocimum tenuiflorum } \\
\text { (black tulsi) }\end{array}$ \\
\hline (Anupriya et al., 2016) & Kigelia Africana \\
\hline $\begin{array}{l}\text { (Baishya, Sharma, \& } \\
\text { Bora, 2012) }\end{array}$ & $\begin{array}{l}\text { Bryophyllum pinnatum } \\
\text { (Lam.) }\end{array}$ \\
\hline $\begin{array}{l}\text { (Logeswari, } \\
\text { Silambarasan, } \\
\text { Abraham, 2012) }\end{array}$ & $\begin{array}{l}\text { Ocimum } \\
\text { tenuiflorum, Solanum } \\
\text { tricobatum, Syzygium } \\
\text { cumini,Centella } \\
\text { asiatica and Citrus } \\
\text { sinensis }\end{array}$ \\
\hline
\end{tabular}
(Ahmed, Ahmad, \& $\begin{aligned} & \text { Azadirachta } \\ & \text { aqueous }\end{aligned}$
Swami, 2015)

(Ghosh et al., 2012) Dioscorea bulbifera

(Ahmad \& Sharma, Ananas comosus 2012)

(Krithiga, Rajalakshmi, Jayachitra, 2015)

\section{Clitoria}

\& ternatea and Solanum nigrum

(Ganaiea, Abbasia, \& Mimosa pudia Abbasia, 2015) Important finding

Prepared AgNPs demonstrated excellent antibacterial and antifungal activity

Particle size of $20-50 \mathrm{~nm}$ with significantly higher antimicrobial activities against Escherichia coli (E. coli) and Bacillus sp. and aso exhibited better rates of germination and oxidative stress enzyme activity for toxicity assay on seeds of Moong Bean (Vigna radiata) and Chickpea (Cicer arietinum)

Prepared AgNPs demonstrated excellent antibacterial activity against Staphylococcus aureus and Escherichia coli

Prepared AgNPs demonstrated promising antibacterial activity against $E$. coli and Staphylococcus aureus.

Antimicrobial activity of the silver bionanoparticles was performed by well diffusion method against Staphylococcus aureus, Pseudomonas aeruginosa, Escherichia coli and Klebsiella pneumoniae. The highest antimicrobial activity of silver nanoparticles synthesized by $S$. tricobatum, O. tenuiflorum extracts was found against $S$. aureus $(30 \mathrm{~mm})$ and $E$. coli $(30 \mathrm{~mm})$ respectively.

indica Green synthesis procedure since only $15 \mathrm{~min}$ were required for the conversion of silver ions into silver nanoparticles at room temperature, without the involvement of any hazardous chemical

Significant antibacterial activity against Pseudomonas aeruginosa and Eschericia coli

The synthesis procedure using pineapple juice is a rapid synthesis for producing stable silver nanoparticles with average size of $12 \mathrm{~nm}$

Synthesis procedure revealed the polydispersed nanoparticles ranged in size from 10 to $50 \mathrm{~nm}$

The synthesis procedure is simple, tailorable, nonpolluting, inexpensive, and nonhazardous and raises the possibility of large-scale

of the AgNPs(Anupriya, Elangovan, Aravind, \& Murugesan, 2016). By considering some aspects in the green chemistry principles the use of low cost and efficient methods for silver nanoparticles were reported. One interesting and widely chosen method is the utilization of plant extract as reducing 
agent in the AgNPs synthesis instead of $\mathrm{NaBH}_{4}$ (Aitenneite et al., 2016; Mavani \& Shah, 2013). The renewable, low cost and greener properties of the plant extract are the important characteristics for such specific form and size of nanoparticles as listed in Table 1.

Beside of the plant extract utilizations, application of low cost and efficient time synthesis by using some specific methods were also investigated. Sonication procedure is one succeed procedure to find time and energy efficient to synthesize AgNPs (Firdhouse \& Lalitha, 2015; Gopinath, Narchonai, Dhanasekaran, Ranjani, \& Thajuddin, 2015; Sharma et al., 2014). Other method is light/sunlight induced method and microwave irradiation method (Nazeruddin et al., 2014; Velusamy, Das, \& Pachaiappan, 2015)(Patil et al., 2016; Srikar, Giri, Pal, Mishra, \& Upadhyay, 2016). Among those, microwave irradiation method is getting increasing attention due to its efficient and environmentally-friendly nature, and it has been implemented as a viable technique in the synthesis of some nanostructure (Aitenneite et al., 2016). From previous reports, the combination of biogenic synthesis using plant extract and sunlight inducing was reported to be effective and environmentally benign process.

In another side, Putri Malu (Mimosa pudica) is one of unused and shrub plant easily growing in tropical area including Indonesia (Figure 1). As stated in Table 1, the use of Mimosa pudica leaf extract was also reported by some investigations, but so far the use of microwave irradiation (MW) method utilizing Mimosa pudica leaf extract has not been reported yet. In order to enhance the effectivity of the use of Mimosa pudica leaf extract in the synthesis of AgNPs, this research is aimed to apply microwave irradiation method in the synthesis. Effect of the microwave irradiation method to the AgNPs particle size distribution and also antibacterial activity was studied. The antibacterial activity of prepared AgNPs was studied against E.coli and P. aeruginosa.

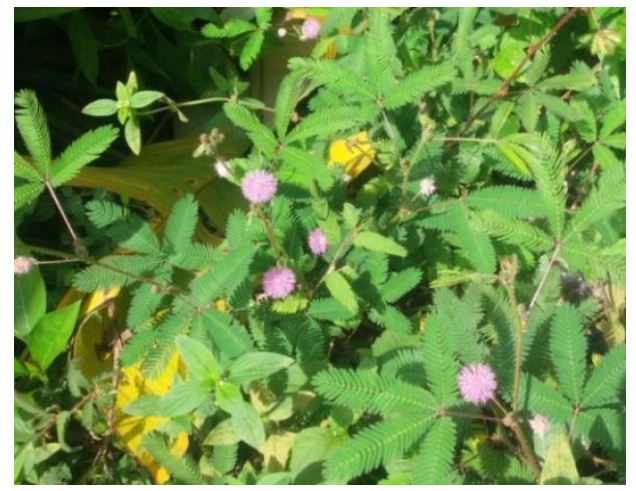

Figure 1. Putri malu (Mimosa pudica) plant

\section{MATERIALS AND METHOD}

\section{Materials}

Mimosa pudica leaves were collected from Universitas Islam Indonesia Campus. The leaves were dried under sunlight before use. Silver nitrate $\left(\mathrm{AgNO}_{3}\right)$ salt, methanol and other chemicals were purchased from Merck, Germany. For antibacterial activity test, readymade potato dextrose agar (PDA) was used. The extract of Mimosa pudica leaves extract (MPE) was obtained by refluxing $10 \mathrm{~g}$ of dry leaves in water for $2 \mathrm{~h}$.

\section{Analytical Instruments}

In order to monitor and characterize the resulted AgNPs, some instrumentations were used. UV-Visible spectrophotometry of HITACI U2010 and FTIR-ATR Perkin Elmer were employed for a spectrophotometric structural change of AgNPs. For particle size distribution, a Horiba particle size analyzer was utilized. In addition, TEM analysis was conducted by using JEOL-JEM 1400. Furthermore in order to ensure the particles morphology and phase SEM-EDX and XRD analyses were performed. The AgNPs solutions were evaporated slowly to get very fine particles to be a thin layered onto glass slide before XRD and SEM-EDX analysis. SEM-EDX was engaged by 
using Phenom-X instrument while for XRD Shimadzu X6000 was employed. $\mathrm{Ni}$-filtered $\mathrm{Cu}-\mathrm{K} \alpha$ radiation was used for the measurements with the step size of $0.02 \%$ mins.

\section{Synthesis and characterization of AgNPs}

Synthesis of AgNPs was conducted by mixing $90 \mathrm{~mL}$ of silver nitrate $\left(\mathrm{AgNO}_{3}\right)$ $0.1 \mathrm{M}$ solution with $10 \mathrm{~mL}$ of MPE at room temperature. For microwave irradiation method, the mixture was irradiated by using commercial microwave under $450 \mathrm{~W}$ power for varied time: 5 mins and $15 \mathrm{mins}$. A modified commercial microwave oven with the scheme in Figure 2 was utilized.

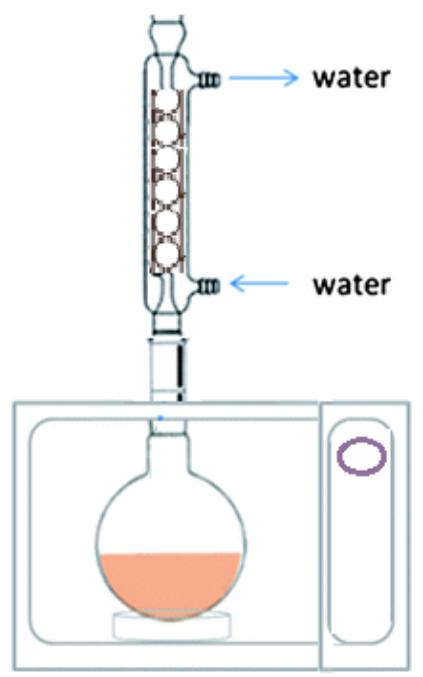

Figure 2. Schematic representation of microwave reactor

For comparison purpose aging method was applied by keeping the mixture under a dark condition at room temperature for a night. By both methods the AgNPs designated as AgNPs$m w$ (obtained by microwave irradiation) and AgNPs-aging(aging for 24h). In the meantime, the color change of the mixture from faint light to yellowish brown to reddish brown was monitored periodically by UV-visible spectrophotometry scanning.

\section{Antibacterial Test}

The synthesized silver nanoparticles were tested for their antibacterial activity to the cultures of Escherichia coli and Pseudomonas aeruginosa by using the disk diffusion method. The disk diffusion was performed by placing different types of disks after immersion in the AgNPs solution. For comparison purposes, chloramphenicol was used as standard antibiotic. The disks in agar plates were incubated for $24 \mathrm{~h}$ at $37{ }^{\circ} \mathrm{C}$ and then the zones of inhibition were calculated.

\section{RESULTS AND DISCUSSION}

Figure 3 shows the photographs of MPE, MPE after the addition of $\mathrm{AgNO}_{3}$ solution of AgNPs resulted by two methods. It is visually a visible color change from transparent to brown after microwave irradiation while a lighter color appears by aging for $24 \mathrm{~h}$. The color change indicates a growth or formation of silver nanoparticles in the solution

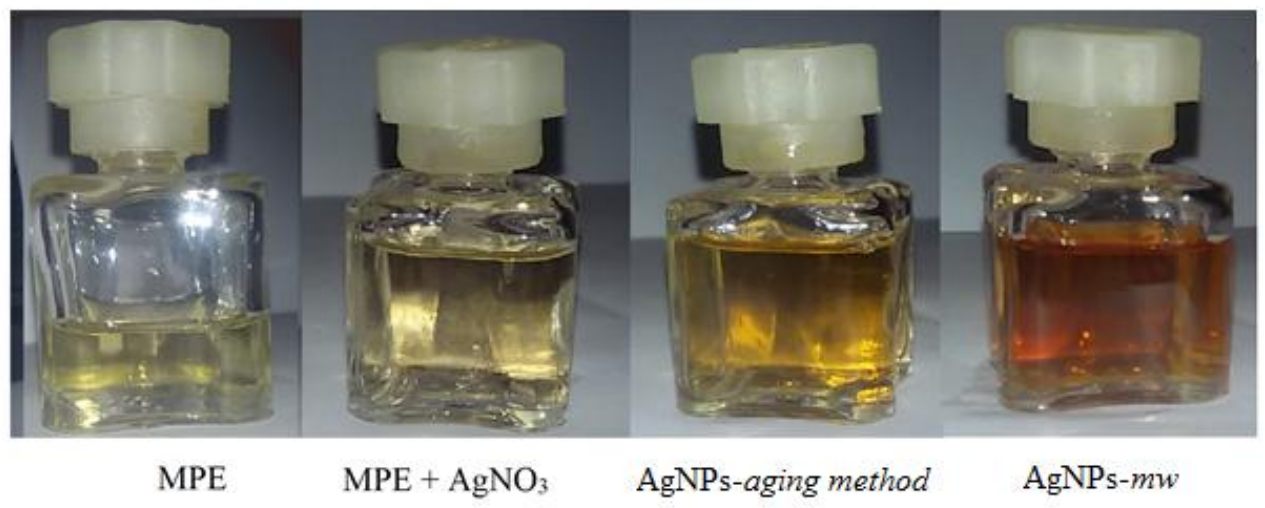

Figure 3. Color change of MPE to formed AgNPs 


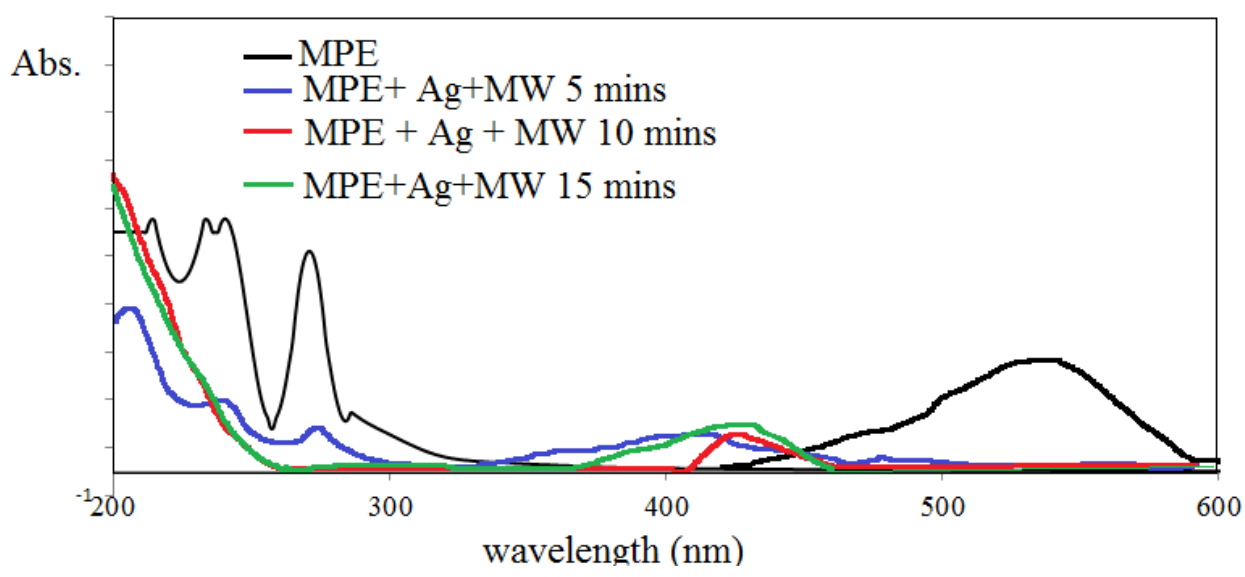

Figure 4. UV-Visible spectra of MPE and AgNPs solution

To confirm the formation of AgNPs, UVvisible spectrophotometer scan at various time intervals of MW irradiation was performed and the spectra is presented in Figure 4. Some intense peaks at $200-300 \mathrm{~nm}$ instead of at $550 \mathrm{~nm}$ are displayed by the MPE and after the reaction, there are some changes especially the shift of the peak at $550 \mathrm{~nm}$ to $450 \mathrm{~nm}$.

The shift indicating the oxidation of MPE organic content and it is also confirmed by the increasing absorbance at increasing time of irradiation. Furthermore the comparison of the FTIR spectra of MPE and the resulted AgNPs is displayed in Figure 5.

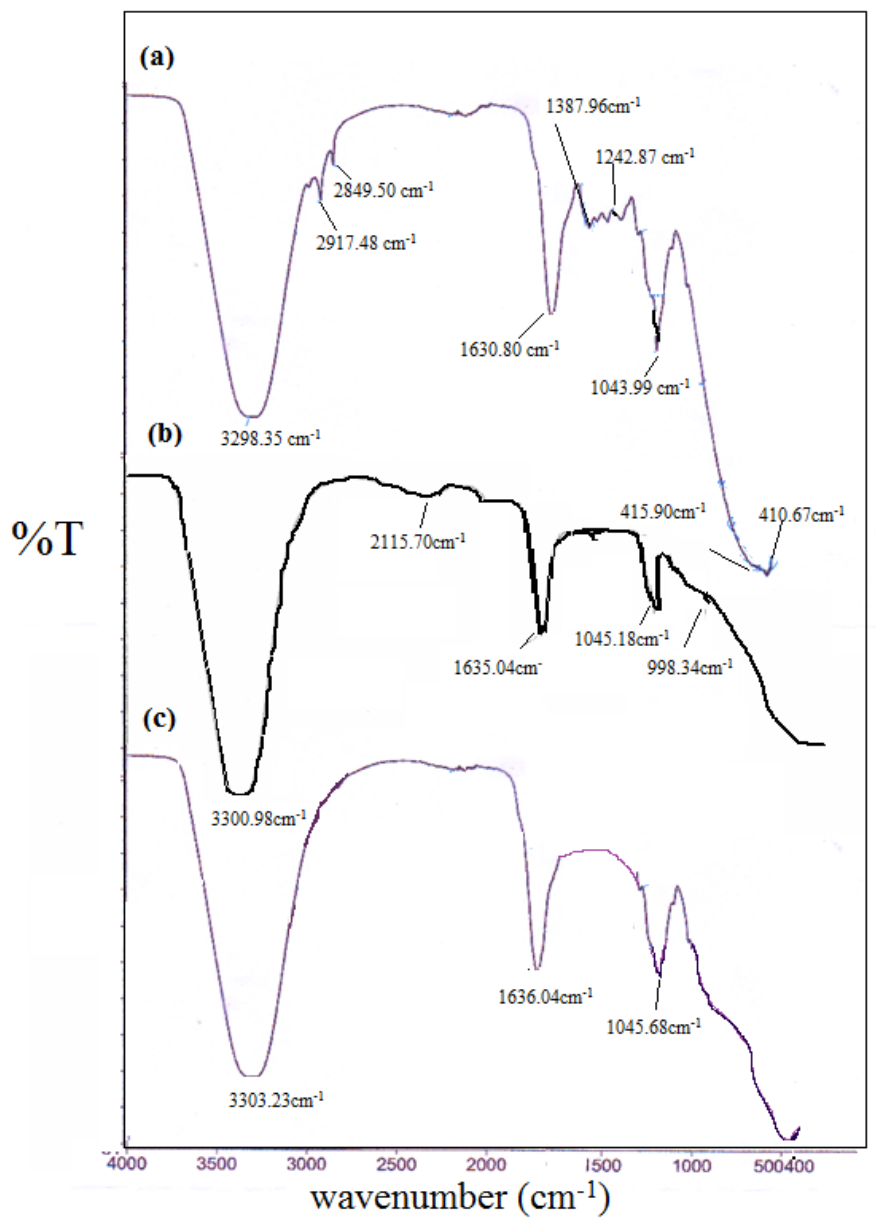

Figure 5. FTIR spectra of (a) MPE (b) AgNPs-mw (c) AgNPs-aging 
Several major peaks at $3298.35,2917.48$, $2849.50,1630.80,1387.96,1242.87$ and $1043.99 \mathrm{~cm}^{-1}$ and some other peaks at around $400-500 \mathrm{~cm}^{-1}$. The peak at 1630.80 $\mathrm{cm}^{-1}$ is designated from the stretching vibration of an amide bond. The peak at $3298.35 \mathrm{~cm}^{-1}$ represents the $-\mathrm{OH}$ stretching vibration come from some phenolic compounds in the extract while the other three peaks at 2849.5, 1387.96 and $1043.99 \mathrm{~cm}^{-1}$ are attributed to $\mathrm{CH}$ stretching vibration, $\mathrm{C}-\mathrm{O}$ stretch and $\mathrm{C}-\mathrm{N}$ stretching of amine contained in organic compounds respectively. After the AgNPs formation, there are some shifts of valuable peaks such as the $\mathrm{O}-\mathrm{H}$ vibration, $\mathrm{C}=\mathrm{O}$ vibration and $\mathrm{N}-\mathrm{H}$ vibration to higher wavenumber. The higher wavenumber means the higher vibration energy required and it can suggest the higher energy vibration caused by the presence of AgNPs. By two varied AgNPs, the similar trend is found.

The XRD patterns of AgNPs resulted (Figure 6) indicate the AgNPs with the face centered cubic (fcc) lattice of silver respect to the standard data (JCPDS file No.01-071-4613). The reflections at $2 \theta$ degree of 38.2, 18744.3 , 64.5 and 77.1 corresponded to the (111), (200), (220), and (311) planes, respectively. Two other reflections at around $38-39^{\circ}$ are unknown and probably come from glass slide used for the filmmaking. From the patterns it is also concluded that the method give no clearly effect to the AgNPs crystallinity. From the calculation using the Scherrer's formula for the crystallite domain size:

$$
\mathrm{D}=0.94 \lambda / \beta \cos \theta
$$

The crystallite size of AgNPs-mw and AgNPs-aging are about $17.9 \mathrm{~nm}$ and $17.6 \mathrm{~nm}$. The Ag NPs-mw is slightly bigger in size than Ag NPs-aging.

The morphology of AgNPs prepared at different methods were examined using SEM-EDX analysis and the result is displayed in Figure 7. It was found that there is no significant difference of AgNPs obtained by MW irradiation and aging method. AgNPs are observed as aggregates and from the EDX spectra it is found that both AgNPs contain $\mathrm{Ag}$ and $\mathrm{O}$ which is probably come from air or solvent residue. The aggregate formed are probably come from the sample preparation for EDX measurement in that the AgNPs were obtained by filtering the solution and filming on the silica slide. In order to ensure the effect of preparation method on the particles sizes, particle size analysis by dynamic light scattering method.

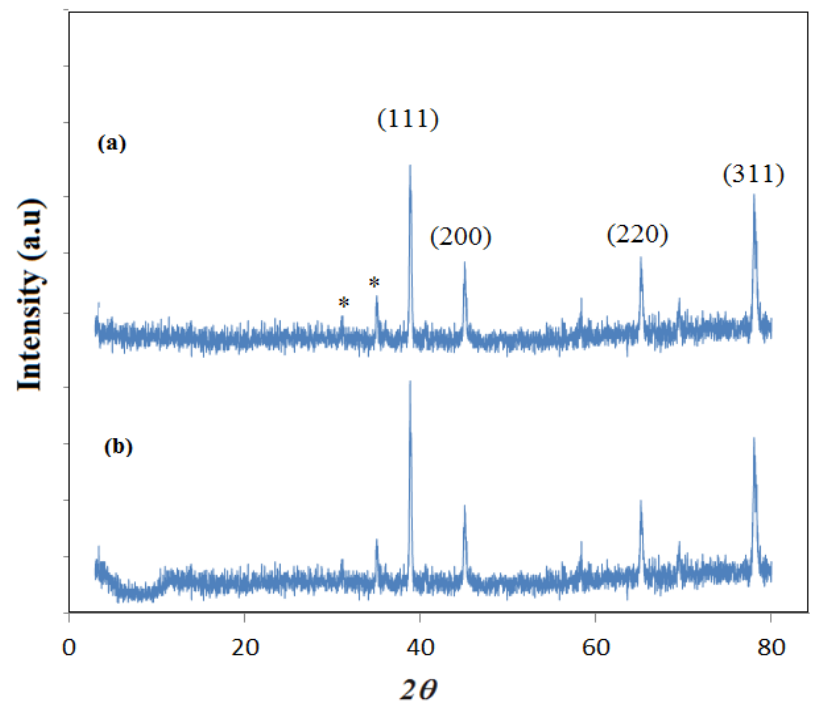

Figure 6. XRD pattern of (a) AgNPs-mw (b) AgNPs-aging 

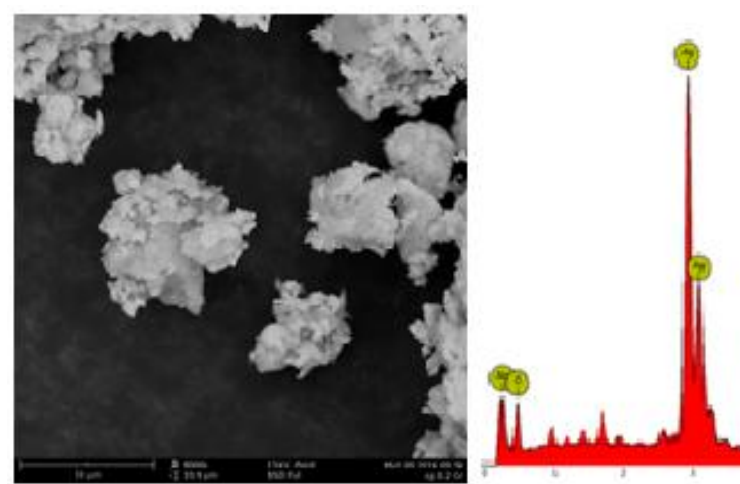

(a)
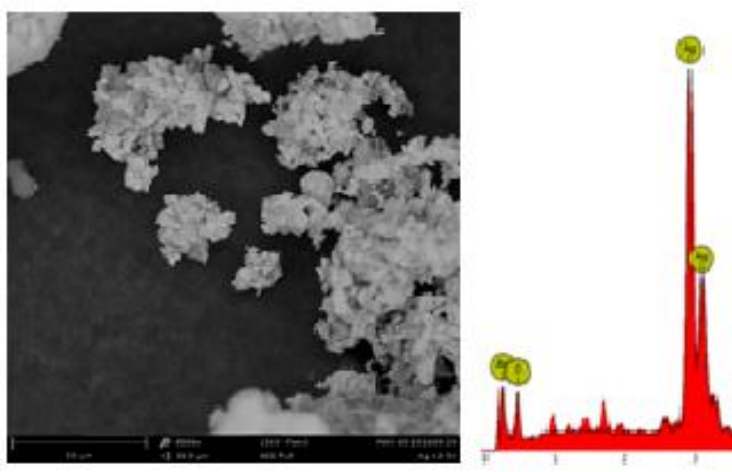

Figure 7. SEM-EDX profile of (a) AgNPs-mw (b) AgNPs-aging

The distribution curves of particle size presented in Figure $\mathbf{8}$ express the effect of preparation method to the distribution. AgNPs- $m w$ exhibits the uniformly distributed particle size material compared with AgNPs-aging as well as the mean particle size diameter of AgNPs$m w$ is smaller $(113.8 \mathrm{~nm})$ that that of AgNPs-aging $(145.1 \mathrm{~nm})$. The possible reason for these data is that microwave irradiation gives very fast acceleration to the $\mathrm{Ag}$ reduction and it may affect the fast formation and autocatalyze Ag reduction rather than that of aging method (Dzido, Markowski, Malachowska-Jutsz, Prusik, \& Jarziebski, 2015). Compared to previous research in the AgNPs synthesis using the microwave, the mean particle size data obtained by this work is bigger and the distribution is not as homogeneous as reported before. The uniform particle size can be obtained by the presence of stabilizing agent (Zhu, Shi, Pan, Liu, \& Zhou, 2013).

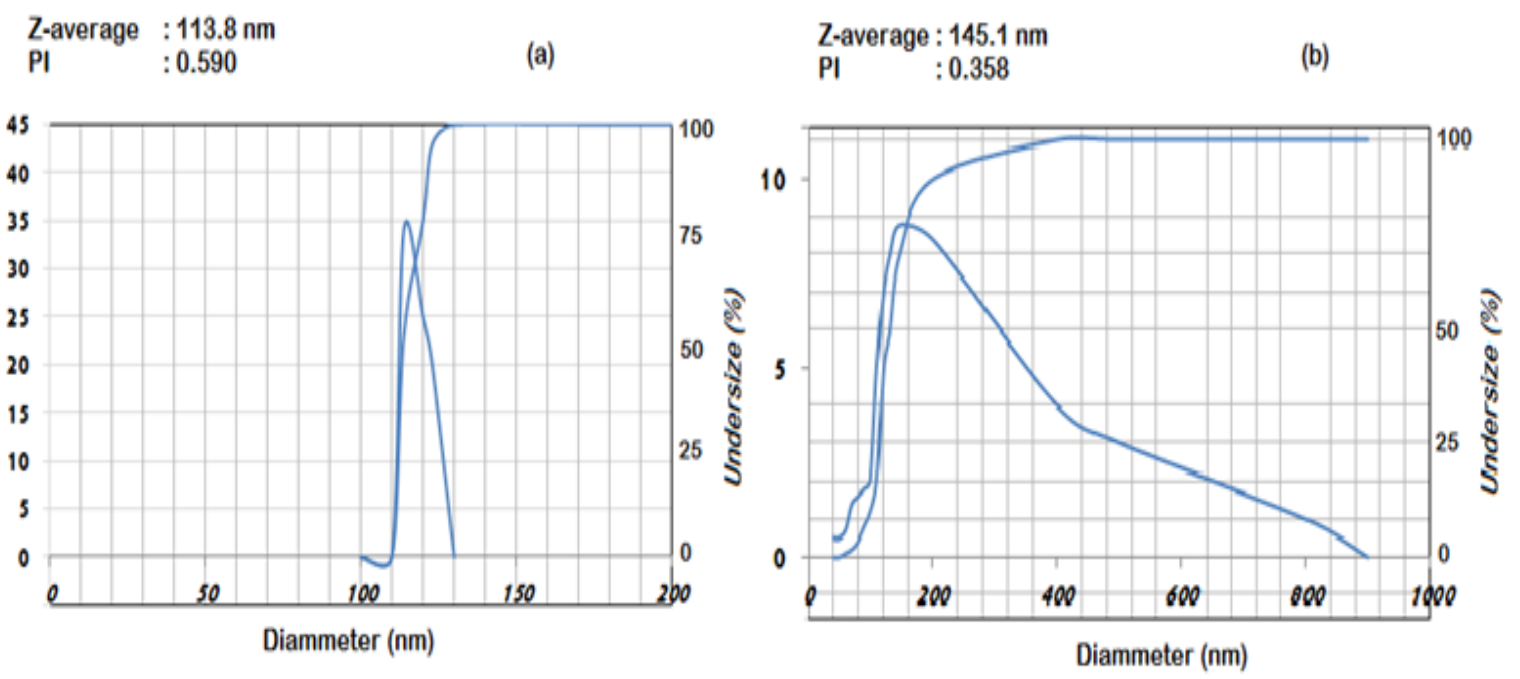

Figure 8. Particle size distribution of (a) AgNPs- $m w$ (b) AgNPs-aging 


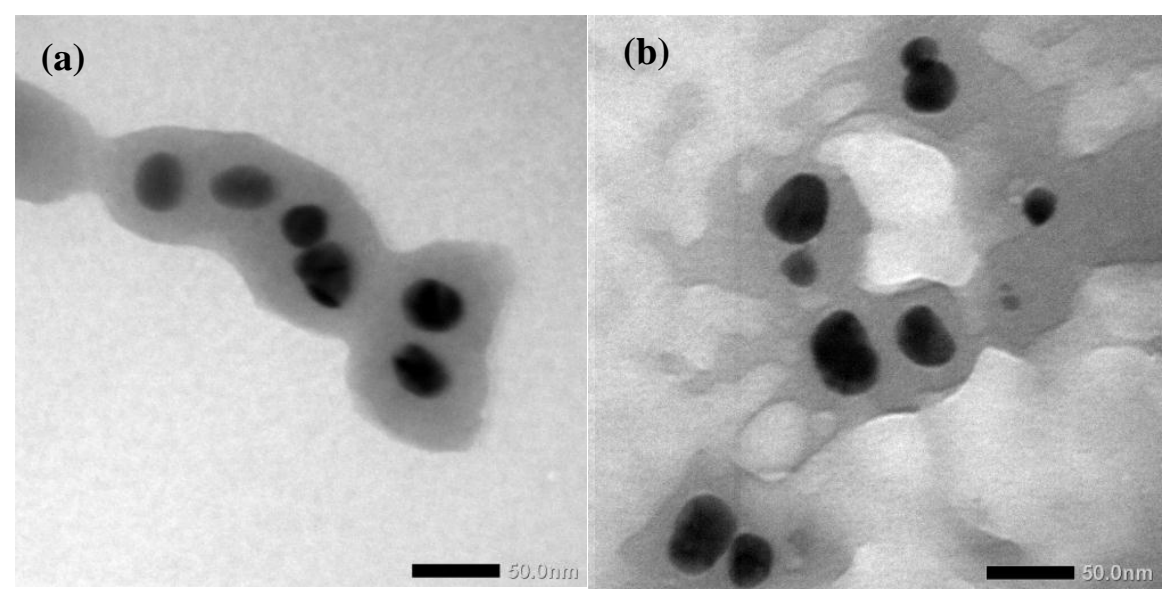

Figure 9. TEM profile of (a) AgNPs- $m w$ (b) AgNPs-aging

In order to ensure the profile of AgNPs, TEM analysis was conducted and the profiles are presented in Figure 9. The figures express the formation of nanoparticles in the size of around 20-50 $\mathrm{nm}$ with capping profile due to the presence of plant extract in the solutions. This is also the reason of its difference with particle size analysis data confirming the mean distribution at more than 100 $\mathrm{nm}$. The presence of plant extract is also advantageous of plant extract-mediated AgNPs synthesis for improving bioactivity as well as chemical stability (Roy \& Das, 2015).

Table 2. Antibacterial assay data of AgNPs

\begin{tabular}{|c|c|c|c|c|c|}
\hline \multirow{3}{*}{$\begin{array}{l}\text { Sample } \\
\text { no }\end{array}$} & \multirow{3}{*}{ Test organism } & \multicolumn{2}{|c|}{ E.coli } & \multicolumn{2}{|c|}{ P. aeruginosa } \\
\hline & & \multicolumn{2}{|c|}{$\begin{array}{c}\text { Zone of inhibition }(\mathrm{mm}) \text { at } \\
\text { varied conc. }\end{array}$} & \multicolumn{2}{|c|}{$\begin{array}{c}\text { Zone of inhibition }(\mathrm{mm}) \text { at } \\
\text { varied conc. }\end{array}$} \\
\hline & & $200 \mu \mathrm{g} / \mathrm{mL}$ & $20 \mu \mathrm{g} / \mathrm{mL}$ & $200 \mu \mathrm{g} / \mathrm{mL}$ & $20 \mu \mathrm{g} / \mathrm{mL}$ \\
\hline $\mathrm{m} 1-\mathrm{m} 2$ & AgNPs-MW & 10.3 & 10.3 & 11.7 & 11.7 \\
\hline $\mathrm{nm} 1-\mathrm{nm} 2$ & AgNPs-aging & 10.4 & 10.6 & 12.0 & 11.7 \\
\hline- & MPE extract & 5.8 & nd & nd & nd \\
\hline- & chloramphenicol & 22.1 & $\begin{array}{c}\text { Not } \\
\text { measured }\end{array}$ & 10.4 & $\begin{array}{c}\text { Not } \\
\text { measured }\end{array}$ \\
\hline- & Aquadest & 0 & 0 & 0 & 0 \\
\hline
\end{tabular}

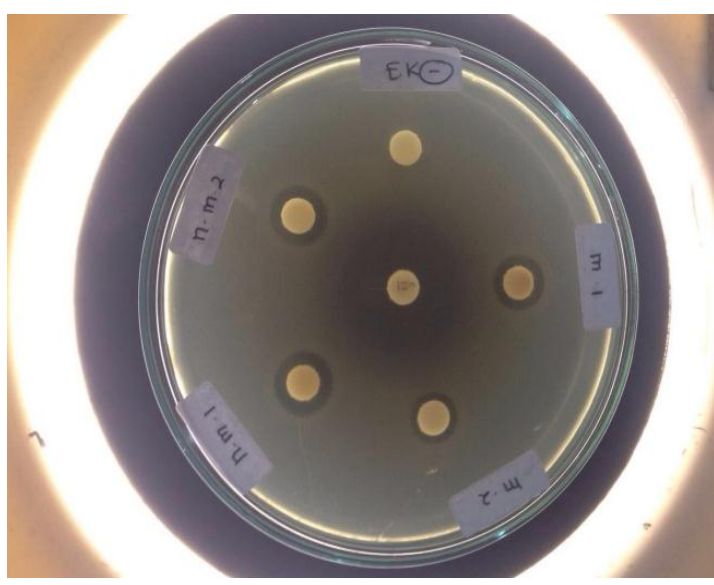

(a)

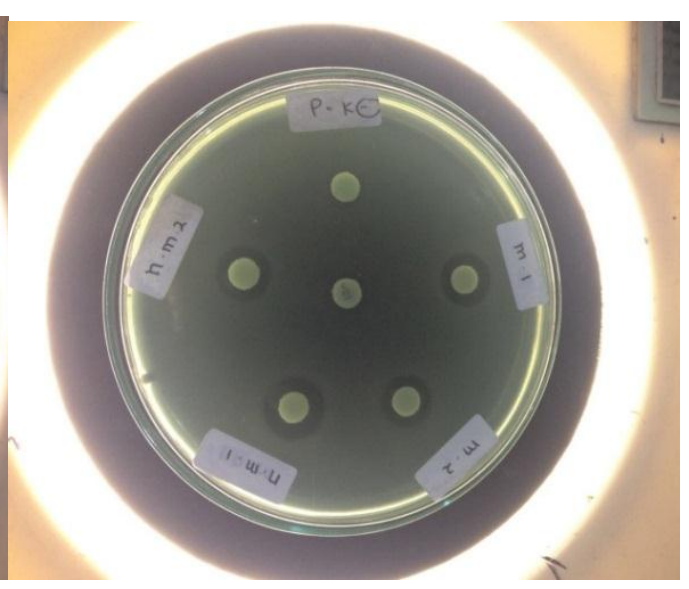

(b)

Figure 10. Antibacterial assay of AgNPs against (a) E.coli (b) P.aeruginosa 
Antibacterial activity assay of the AgNPs (Figure $\mathbf{1 0}$ and Table 2) demonstrates the insignificant data correspond to the active antibacterial AgNPs from both preparation methods. In general concentration of AgNPs is also not affecting to the activity for both organisms. It can be noted that for both microorganism, AgNPs- $m w$ give slightly higher inhibition zone compared with AgNPs-aging. From the compared activity, the advantageous of MW utilization becomes a strategically method to have similar activity in a shorter time of synthesis.

\section{CONCLUSION}

The biosynthesis of silver nanoparticles (AgNPs) using Mimosa pudica leaf extract (MPE) by using microwave irradiation method has been successfully investigated. It is found that microwave irradiation method give the similar physicochemical character of AgNPs compared to aging method. From the particle size distribution and also TEM analysis it is found that microwave irradiation affects to the more homogeneous and smaller particle size distribution of the AgNPs. However, the antibacterial activity against both E.coli and $P$ aeruginosa is not significantly different so in general MW utilization in AgNPs synthesis contributes to the more time-effective of synthesis.

\section{ACKNOWLEDGEMENTS}

The authors acknowledge with thanks the Department of Chemistry, Universitas Islam Indonesia for providing the financial assistance in the research activity, Laboratory of Water Quality, Department of Environmental Engineering, Universitas Islam Indonesia for SEM-EDX analysis and Laboratory of Pharmaceutical Technology, Universitas Islam Indonesia for particle size analysis instrument.

\section{REFERENCES}

Ahmad, N., \& Sharma, S. (2012). Green
Synthesis of Silver Nanoparticles Using Extracts of Ananas comosus. Green and Sustainable Chemistry, 2(November), 141-147. http://doi.org/10.4236/gsc.2012.2402 0

Ahmed, S., Ahmad, M., \& Swami, B. L. (2015). ScienceDirect Green synthesis of silver nanoparticles using Azadirachta indica aqueous leaf extract. Journal of Radiation Research and Applied Sciences, 9(1), $1-7$.

http://doi.org/10.1016/j.jrras.2015.06. 006

Aitenneite, H., Abboud, Y., Tanane, O., Solhy, A., Sebti, S., \& Bouari, A. El. (2016). Rapid and green microwaveassisted synthesis of silver nanoparticles using aqueous Phoenix Dactylifera L . ( date palm ) leaf extract and their catalytic activity for 4-Nitrophenol reduction. Journal of Material and Environmental Sciences, 7(7), 2335-2339.

Anupriya, S., Elangovan, K., Aravind, R., \& Murugesan, K. (2016). Synthesis of Silver Nanoparticles Stabilized With Phytochemicals and its Application towards Invitro Antioxidant and Antibacterial Activities. International Journal of Medicine and Nanotechnology, 3(2), 340-349.

Baishya, D., Sharma, N., \& Bora, R. (2012). Green Synthesis of Silver Nanoparticle using Bryophyllum pinnatum ( Lam .) and monitoring their antibacterial activities. Archives of Applied Science Research, 4(5), 2098-2104.

Banerjee, P., Satapathy, M., Mukhopahayay, A., \& Das, P. (2014). Leaf extract mediated green synthesis of silver nanoparticles from widely available Indian plants: synthesis, characterization, antimicrobial property and toxicity analysis. Bioresources and Bioprocessing, $\quad 1(1), \quad 3$. 
http://doi.org/10.1186/s40643-0140003-y

Dos Santos, C. A., Seckler, M. M., Ingle, A. P., Gupta, I., Galdiero, S., Galdiero, M., ... Rai, M. (2014). Silver nanoparticles: Therapeutical uses, toxicity, and safety issues. Journal of Pharmaceutical Sciences, 103(7), 1931-1944. http://doi.org/10.1002/jps.24001

Dzido, G., Markowski, P., MalachowskaJutsz, A., Prusik, K., \& Jarziebski, A. B. (2015). Rapid continuous microwave-assisted synthesis of silver nanoparticles to achieve very high productivity and full yield: from mechanistic study to optimal fabrication strategy. Journal of Nanoparticle Research, 17(1), 1-15. http://doi.org/10.1007/s11051-0142843-y

Firdhouse, M. J., \& Lalitha, P. (2015). Biosynthesis of silver nanoparticles and its applications. Journal of Nanotechnology, 2015(September 2014).

http://doi.org/10.1155/2015/829526

Ganaiea, S. U., Abbasia, T., \& Abbasia, S. A. (2015). Green Synthesis of Silver Nanoparticles Using an Otherwise Worthless Weed Mimosa (Mimosa pudica): Feasibility and Process Development Toward Shape/Size Control. Particulate Science and Technology: An International Journal, 6(33), 638-644.

Ghosh, S., Patil, S., Ahire, M., Kitture, M., Kale, S., Pardesi, K., ... BA, C. (2012). Synthesis of silver nanoparticles using Dioscorea bulbifera tuber extract and evaluation of its synergistic potential in combination with antimicrobial agents. International Journal of Nanomedicine, 7, 483-496.

Gopinath, P. M., Narchonai, G., Dhanasekaran, D., Ranjani, A., \& Thajuddin, N. (2015). Mycosynthesis, characterization and antibacterial properties of AgNPs against multidrug resistant (MDR) bacterial pathogens of female infertility cases. Asian Journal of Pharmaceutical Sciences, 10(2), 138-145.

http://doi.org/10.1016/j.ajps.2014.08. 007

Krithiga, N., Rajalakshmi, A., \& Jayachitra, A. (2015). Green Synthesis of Silver Nanoparticles Using Leaf Extracts of Clitoria ternatea and Solanum nigrum and Study of Its Antibacterial Effect against Common Nosocomial Pathogens, 2015.

Logeswari, P., Silambarasan, S., \& Abraham, J. (2012). Synthesis of silver nanoparticles using plants extract and analysis of their antimicrobial property. Journal of Saudi Chemical Society, 19(3), 311317.

http://doi.org/10.1016/j.jscs.2012.04. 007

Mavani, K., \& Shah, M. (2013). Synthesis of Silver Nanoparticles by using Sodium Borohydride as a Reducing Agent. International Journal of Engineering Research \& Technology, 2(3), $1-5$. http://doi.org/10.13140/2.1.3116.864 8

Nazeruddin, G. M., Prasad, N. R., Prasad, S. R., Shaikh, Y. I., Waghmare, S. R., \& Adhyapak, P. (2014). Coriandrum sativum seed extract assisted in situ green synthesis of silver nanoparticle and its antimicrobial activity. Industrial Crops \& Products, 60, 212-216. http://doi.org/10.1016/j.indcrop.2014 .05 .040

Patil, S. S., Mali, M. G., Tamboli, M. S., Patil, D. R., Kulkarni, M. V., Yoon, H., ... Kale, B. B. (2016). Green approach for hierarchical nanostructured $\mathrm{Ag}-\mathrm{ZnO}$ and their photocatalytic performance under sunlight. Catalysis Today, 260, 126134. 
http://doi.org/10.1016/j.cattod.2015.0 6.004

Rout, Y., Behera, S., Ojha, A. K., \& Nayak, P. L. (2012). Green synthesis of silver nanoparticles using Ocimum sanctum ( Tulashi ) and study of their antibacterial and antifungal activities. Journal of Microbiology and Antimicrobials, 4(6), 103-109. http://doi.org/10.5897/JMA11.060

Roy, S., \& Das, T. K. (2015). Plant Mediated Green Synthesis of Silver Nanoparticles-A Review. International Journal of Plant Biology and Research, 3(3).

Sharma, G., Sharma, A. R., Kurian, M., Bhavesh, R., Nam, J. S., \& Lee, S. S. (2014). Green synthesis of silver nanoparticle using Myristica fragrans (nutmeg) seed extract and its biological activity. Digest Journal of Nanomaterials and Biostructures, 9(1), 325-332.
Srikar, S. K., Giri, D. D., Pal, D. B., Mishra, P. K., \& Upadhyay, S. N. (2016). Light Induced Green Synthesis of Silver Nanoparticles Using Aqueous Extract of Prunus amygdalus. Green and Sustainable Chemistry, 6(February), 26-33.

Velusamy, P., Das, J., \& Pachaiappan, R. (2015). Greener approach for synthesis of antibacterial silver nanoparticles using aqueous solution of neem gum ( Azadirachta indica L .). Industrial Crops \& Products, 66, 103-109. http://doi.org/10.1016/j.indcrop.2014 .12 .042

Zhu, J., Shi, J., Pan, Y., Liu, X., \& Zhou, L. (2013). Synthesis of uniform silver nanoparticles by a microwave method in polyethylene glycol with the assistant of polyvinylpyrrolidone. Wuhan University Journal of Natural Sciences, 18(6), 530-534. 